\title{
The Prospective Protective Effect of Selenium Against Chronic Restraint Stress-Induced Memory Impairment in Male Albino Rats
}

\author{
ISLAM I. HEGAB, M.D.*; RAMEZ A.E. BARHOMA, M.D.*; RANIA N. ABD EL-LATIF, M.D.** and \\ RASHA EL-ESAWY, M.D.*** \\ The Departments of Physiology*, Biochemistry** and Pharmacology***, Faculty of Medicine, Tanta University, Egypt
}

\begin{abstract}
Background: Selenium (Se) had underscored many beneficial neuroprotective potentials, particularly with respect to learning and memory. However, the protective effect of Se in memory impairment associated with Chronic Restraint Stress (CRS) is not yet elucidated.
\end{abstract}

Aim of Study: The present study was carried out to examine the effect of Se treatment against CRS induced behavioral and biochemical abnormalities.

Material and Methods: The stress was induced by restraining the animals in well ventilated tubes $(6 \mathrm{~h} / \mathrm{d})$ for consecutive 21 days. Animals were randomly divided into 4 groups (8 rats each): Normal control, drug control, CRS and Se treated CRS groups. After 21 days of the experiment, memory function was evaluated by Passive Avoidance (PA), T-maze and object recognition tasks. Hippocampal oxidative stress markers, Brain Derived Neurotrophic Factor (BDNF), amyloid P (AR) protein, phosphorylated TAU (p-TAU) protein as well as glutamate and acetylcholinestrase activity (AchE) levels were assessed.

Results: This study revealed that the memory performance was markedly deteriorated in CRS group, accompanied by noticeable alterations in hippocampal oxidative stress markers, depleted levels of BDNF together with overproduction of AP p-TAU and glutamate as well as, excessive activity of AchE enzyme. Meanwhile, these behavioral and biochemical deviations were alleviated under 21 days of Se co-treatment in CRS exposed rats.

Conclusion: This study proved the beneficial protective effects of Se in CRS-induced memory deficits and its associated pathological changes in rats, which may draw the attention to $\mathrm{Se}$ as a new therapeutic candidate for memory dysfunction associated with stress and its related disorders.

Key Words: Selenium - Chronic restraint stress - Memory impairment - Passive avoidance - T maze.

\section{Introduction}

STRESS is a physiological or psychological response evoked by adverse stimuli, which may

Correspondence to: Dr. Islam Ibrahim Hegab, E-Mail: dr.islamhegab@gmail.com disturb the homeostasis of the body especially brain functions [1]. Chronic stress can trigger the activity of the hypothalamic-pituitary-adrenal axis, increasing the circulating levels of the stress hormones, Glucocorticoids (GC) [2]. One of the most vulnerable targets of stress is hippocampus, which is a limbic region important in learning and memory, and abundantly expresses GC receptors [3] Stress activates hippocampal glucocorticoid receptors, increases neuronal metabolism, decreases cell survival and neurogenesis, triggers dendritic atrophy and causes long-term potentiation and cognitive deficits $[4,5]$. In addition, chronic stress was correlated with many age-related neurodegenerative diseases as Alzheimer's Disease (AD) [6] .

Chronic restraint stress is a specific and common method used to induce psychological and physiological stress. It is well setted for its ability to impair cognitive hippocampus-dependent functions, particularly learning and memory [7,8]. Many studies demonstrated the possible underlying mechanisms for the pathophysiology of CRS induced memory impairment [9-12]. Nevertheless, few studies have investigated the effectiveness of therapeutic agents for the treatment of chronic stress-induced memory deficits [3]

Selenium has received a considerable attention as an essential trace element, having a pivotal role in maintaining physiological functions. Dietary selenium can exist as selenomethionine, selenocysteine, or selenite [13]. Selenoproteins, such as Glutathione Peroxidase (GPx) and Thioredoxin Reductase (TrxR) enzymes are of particular interest due to their integration in generating antioxidant defense, regulating gene expression, cell viability and proliferation [14]. In addition, Se is a vital mineral for the brain, involved in regulating vital neural antioxidant signaling pathways which 
mediate its beneficial effects against neurotoxicity and oxidative damage in various brain disorders $[15,16]$. A decreased blood selenium level and GPx activity were reported in patients with memory impairment $[\mathbf{1 7 , 1 8}]$. Moreover, Se deficiency has been associated with an increased risk of AD [19]

A number of clinical trials recorded the beneficial role of Se in modulating learning and memory deficits in different neurological disorders including, Alzheimer's disease, scopolamine or lead induced cognitive deficits, $[\mathbf{1 6 , 2 0 , 2 1 ]}$ as well as after transient cerebral hypoxia-ischemia [22]. However, and up to our knowledge, the protective effect of Se on CRS-induced cognitive impairment had not been previously recorded.

Therefore, the present study was designated to investigate the possible neuroprotective effects of Se on CRS-induced cognitive deficits in rats, further dissecting its possible mechanisms involved.

\section{Material and Methods}

Selenium in the form of sodium selenite ( $\left.\mathrm{Na}_{2} \mathrm{SeO}_{3}\right)$ was purchased from Sigma Chemical Co. (St. Louis, MO, USA), and was freshly dissolved in $0.9 \% \mathrm{NaCl}$. All other chemical reagents were obtained from Sigma. Co, unless described otherwise and are of high analytical grade.

\section{Animals and experimental protocol:}

This study was carried out from July 2018 to November 2018, and all procedures were performed in accordance with the guidelines for the animal experimental protocols of Tanta Faculty of Medicine.

Thirty two male adult albino rats weighing 200$250 \mathrm{~g}$, were maintained under standard laboratory conditions, kept on a 12-h light-dark cycle with free access to food and water and were acclimatized to these conditions for at least 1 week prior to the experiment.

Rats were randomly categorized into four equal groups, 8 rats each:

- Group I: Served as normal control group, which was not stressed and had free access to water and food.

- Group-II: Served as drug control group, which was not stressed and received oral Se in the form of sodium selenite dissolved in $0.9 \% \mathrm{NaCl}$ at a dose of $(0.35 \mathrm{mg} / \mathrm{kg} / \mathrm{d})$ for 21 days $[23,24]$

- Group III: Served as CRS group which were exposed to CRS for 6h/day for 21 days.
- Group IV: Served as Se treated CRS group, which received oral sodium selenite at a dose of 0.35 $\mathrm{mg} / \mathrm{kg} / \mathrm{d}$ once daily, 60 minutes prior to exposure to CRS sessions for successive 21 days.

The control and stressed rats were given the same volume of saline.

\section{Induction of chronic restraint stress:}

Each rat was placed in a conical plastic tube $(20 \times 7 \mathrm{~cm})$ for 6 hours (from 10a.m. to 4 p.m.) for successive 21 days. The tip of the restrainer has several small holes to allow sufficient breathing and the rats were unable to move within the tubes, this paradigm was proved to induce cognitive deficits in rats $[\mathbf{1}, \mathbf{3}]$

\section{Behavioral memory tasks:}

At the end of the 3 th week of experiment, behavioral memory tests were performed as follow:

\section{1- Passive avoidance task:}

The passive-avoidance paradigm was used to evaluate the hippocampus-dependent associative memory $[\mathbf{2 5 , 2 6 ]}$, in which animals learned to associate the aversive unconditioned stimulus (mild electric foot-shock) with the conditioned stimulus (the dark chamber). It was assessed using the passive avoidance apparatus which consists of two compartments, one was illuminated and the other was dark which were separated by a sliding door and the task was performed as described previously $[1,27]$

On day 22 of the experiment, each rat was placed in the apparatus for 300 seconds for habituation. On the following day (day 23), a single learning trial was performed in which rats were introduced individually into the light compartment and allowed $1 \mathrm{~min}$ to explore the area before the trap door was opened. Immediately after the mouse entered the dark compartment, the trap door was closed, and 3-5 electric shocks (0.5mA) were applied to the stainless steel floor of the compartment. The initial latency of entrance into the dark room was recorded before inducing the electrical shock.

A retention trial was performed 24-h after the learning trial. Evaluation of recall of this inhibitory stimulus was done by placing the animals in the light compartment and recording their latency to enter the dark compartment. If the animal did not enter the dark compartment within 300sec, it was returned to its cage, and retention latency of $300 \mathrm{sec}$ was recorded, which is an indicator for retention performance of the PA response. Increased retention 
latency time to enter the dark compartment is a good index of long-term memory.

\section{2- The T-maze task:}

The spatial working memory was tested by spontaneous alternation behavior in T-maze tasks [28]. This test depends on the strong exploratory drive of rats, thus rats tend to choose the arm not visited before, reflecting memory of the first choice, this is called spontaneous alternation, which is very sensitive for hippocampal dysfunction [29]

The T maze apparatus was specially designated, which is a black painted wooden $\mathrm{T}$ shaped apparatus, measuring $30 \mathrm{~cm}$ length, $10 \mathrm{~cm}$ width, and $20 \mathrm{~cm}$ height, for start and the two goal arms. Manual guillotine doors were located at the entrances to each arm. In brief, rats were placed into the start arm of T-maze and allowed to choose freely between the two goal arms. Once the rat enters one goal arm, the other arm was closed, where it is confined for a 30 seconds, after which it is placed again in the start arm to start another trial. A total of 6 trials were performed. Alternation was recorded when the mice accessed one arm in the first trial and chose the other arm in the second trial. The percentage of alternation for each animal was calculated (actual alternations/total possible alternations) X 100 [30].

\section{3- Object recognition task:}

Recognition memory was assessed using the object recognition task which needs integrity of hippocampus and depends on the preference of rodents to explore novel objects rather than familiar objects [31].

This task was conducted as described by Bevins and Besheer [32]. Briefly, habituation was done by placing each rat in a dimly illuminated open field box measured $(20 \times 20 \times 17 \times 4)$ for $15 \mathrm{~min}$. The following day, two plastic sample objects about 12 inches apart were placed in one of the boxes and the rats were allowed to explore for $10 \mathrm{~min}$. After $3 \mathrm{~h}$, the retention test was conducted by placing the rats once again in the box, but with a novel object replacing one of the objects placed during the training session. The rats were allowed to explore for $5 \mathrm{~min}$, total time spent exploring each of the two objects was recorded. Recognition Index (RI) was indicator for recognition memory performance, calculated as:

$$
\mathrm{RI}=\frac{\text { Time exploring novel object }}{\text { Time exploring novel object }+} \times 100
$$

Tissue homogenization and biochemical assessment:

After completing the experimental regimen, the animals were sacrificed by cervical decapitation and brains were collected. The hippocampi of each brain were dissected, weighted then homogenized by PBS PH 7.2-7.4, and centrifuged at $4^{\circ} \mathrm{C}$, at a speed of 2000-3000rpm, for 20min. The resultant supernatant was taken and kept frozen till the time of biochemical analysis. Total protein content was estimated based on the method of Bradford [33]

Lipid peroxidation in hippocampal homogenates was determined by measuring Thiobarbituric Acid Reactive Substances (TBARS) as described by Ohkawa et al., [34], while brain activity of GPx and TrxR were assessed based on the method of Chiu et al., [35] and Holmgren and Bjornstedt, [36] respectively. Moreover, hippocampal BDNF and glutamate were evaluated using their respective MyBioSource ELISA kits, while the level of brain $\mathrm{A} \beta$ and $\mathrm{p}$-TAU proteins were detected using Elabscience Biotechnology Co., Ltd. (Wuhan, China) ELISA kits. All Assay procedures were performed according to the manufacturer's guidelines. Finally, AchE activity level was determined by a modified method of Ellman et al., [37]. As described by Gorun et al., [38]

\section{Statistical analysis:}

The data were expressed as the mean \pm standard deviation. Data were analyzed using one-way ANOVA. All the analyses were performed using SPSS for windows (Version 21.0) with Tukey post hoc test analysis. $p$-values $<0.05$ were considered statistically significant.

\section{Results}

Effect of Se on behavioral memory tasks in experimental rats:

As regard the PA task, data of (Table 1) depicted insignificant differences in initial latency values between all studied groups. However, retention latency was significantly reduced in CRS-group as compared to the normal control one, indicating the reduced passive avoidance memory as a result of the restraint stress. Meanwhile, Se co-treatment for 3 weeks significantly enhanced the retention latency in treated CRS group as compared to the untreated CRS one. Noteworthy, the retention latency returned back to near control values by Se co-treatment.

We further explored the beneficial effect of $\mathrm{Se}$ on memory function of CRS-exposed rats using the T maze task. Our data demonstrated a signif- 
icant reduction in the percentage of continuous alternations of $\mathrm{T}$ maze task in CRS rats compared to normal control ones, whereas se co-treatment significantly improved the alternation performance in treated CRS rats versus the untreated CRS ones (Table 1).

The current object recognition paradigm revealed a significant decrease in RI in CRS exposed rats compared to normal control ones, indicating a recognition memory deficits which was significantly improved upon Se co-treatment (Table 1).

Table (1): Effect of Se treatment on behavioral memory tasks in experimental rats.

\begin{tabular}{|c|c|}
\hline Parameters & Group I Group II Group III Group IV \\
\hline - Initial latency of PA (sec) & $40 \pm 3.98 \quad 39 \pm 3.59 \quad 42 \pm 5.71$ \\
\hline $\begin{array}{l}\text { - Retension latency of PA } \\
(\mathrm{sec})\end{array}$ & $178 \pm 16 \quad 192 \pm 21 b \quad 51 \pm 4.7 a$ \\
\hline $\begin{array}{l}\text { - Percentage of spontaneous } \\
\text { alteration }(\%)\end{array}$ & $65 \pm 4.81 \quad 67 \pm 5.44 \mathrm{~b} \quad 41 \pm 3.96 \mathrm{a} \quad 61 \pm 4.79 \mathrm{~b}$ \\
\hline - Recognition index \% & $63 \pm 5.7 \quad 66 \pm 5.5 b \quad 47 \pm 4.6 a \quad 68 \pm 6.4 b$ \\
\hline $\begin{array}{l}\text { Group I : Normal control. } \\
\text { Group II : Drug control. } \\
\text { Group III : CRS. }\end{array}$ & $\begin{array}{l}\text { Data are expressed as mean } \pm \text { SD. } \\
\text { a: } p<0.05 \text { Vs. Group I. } \\
\text { b: } p<0.05 \text { Vs. Group III. }\end{array}$ \\
\hline Group IV : Se-treate & ups. \\
\hline
\end{tabular}

Effect of Se on hippocampal oxidative stress markers in experimental rats:

Results of (Table 2) showed that, compared to the normal control rats, exposure to CRS significantly increased level of TBARS while significantly decreased GPx and TrxR levels in hippocampus. Notably, co-administration of Se, significantly decreased hippocampal levels of TBARS and increased GPx and TrxR in treated CRS rats as compared to untreated CRS-ones, which were restored to near control values.

Table (2): Effect of Se treatment on CRS-induced oxidative stress markers in rats hippocampi.

\begin{tabular}{|c|c|c|c|c|}
\hline Parameters & Group I & Group II & Group III & Group IV \\
\hline $\begin{array}{l}\text { - TBARS (nmol/g } \\
\text { of tissue) }\end{array}$ & $59 \pm 3.07060$ & $55 \pm 2.12 b$ & $992 \pm 4.31 \mathrm{a}$ & $63 \pm 3.81 \mathrm{~b}$ \\
\hline $\begin{array}{l}\text { - GPx (IU/g of } \\
\text { tissue) }\end{array}$ & $26 \pm 2.12$ & $29 \pm 2.31 b$ & $17 \pm 1.78 \mathrm{a}$ & $25 \pm 2 b$ \\
\hline $\begin{array}{l}\text { - TrxR (nmol/min/ } \\
\text { mg protein) }\end{array}$ & $10.6 \pm 0.76$ & $10.9 \pm 0.96 b$ & $7.50 \pm 0.83 \mathrm{a}$ & $10.3 \pm 1.39 b$ \\
\hline $\begin{array}{l}\text { Group I : Normal } \\
\text { Group II : Drug co } \\
\text { Group III : CRS. }\end{array}$ & $\begin{array}{l}\text { control. } \\
\text { ontrol. }\end{array}$ & $\begin{array}{l}\text { Data are e } \\
\text { a: } p<0.05 \\
\text { b: } p<0.05\end{array}$ & $\begin{array}{l}\text { xpressed as I } \\
\text { Vs. Group I. } \\
\text { Vs. Group II }\end{array}$ & $\begin{array}{l}\text { mean } \pm \mathrm{SD} \text {. } \\
\text { II. }\end{array}$ \\
\hline
\end{tabular}

Effect of Se on hippocampal levels of BDNF, $A \beta$ and TAU in experimental rats:

These data were shown in (Table 3), the levels of BDNF were significantly decreased, while A $\beta$ and TAU were significantly increased upon exposure to CRS as compared to the normal control group. Mean while, Se co-treatment significantly reversed these values, but, their levels were still significant versus to those observed in the normal control group.

Table (3): Effect of Se treatment on hippocampal levels of $\mathrm{BDNF}, \mathrm{A} \beta$ and $\mathrm{p}-\mathrm{TAU}$ in experimental rats.

\begin{tabular}{lllll}
\hline Parameters & \multicolumn{1}{c}{ Group I } & Group II & Group III & Group IV \\
\hline BDNF (ng/g tissue) & $132 \pm 6.2$ & $126 \pm 4.7 \mathrm{~b}$ & $99 \pm 4.9 \mathrm{a}$ & $122 \pm 5.2 \mathrm{ab}$ \\
$\mathrm{A} \beta(\mathrm{pg} / \mathrm{ml})$ & $48.9 \pm 3.48$ & $45.3 \pm 2.38 \mathrm{~b}$ & $93.8 \pm 3.69 \mathrm{a}$ & $61.8 \pm 3.37 \mathrm{ab}$ \\
P-TAU (pg/ml) & $83 \pm 5.1$ & $79 \pm 3.8 \mathrm{~b}$ & $130 \pm 5.7 \mathrm{a}$ & $93 \pm 4.6 \mathrm{ab}$ \\
\hline Group I : Normal control. & Data are expressed as mean $\pm \mathrm{SD}$. \\
Group II : Drug control. & a: $p<0.05$ Vs. Group I. \\
Group III: CRS. & b: $p<0.05$ Vs. Group III. \\
Group IV : Se-treated CRS groups.
\end{tabular}

Effect of Se on hippocampal levels of glutamate and AchE activity in experimental rats:

As compiled in Figs. $(1,2)$, rats exposed to CRS showed a significant increase in hippocampal glutamate and AchE activity levels when compared to normal control ones. Interestingly, Se cotreatment showed an insignificant effect on glutamate levels, whereas it significantly reversed the excessive activity of Ach E toward the control values in treated CRS group compared to untreated CRS one.
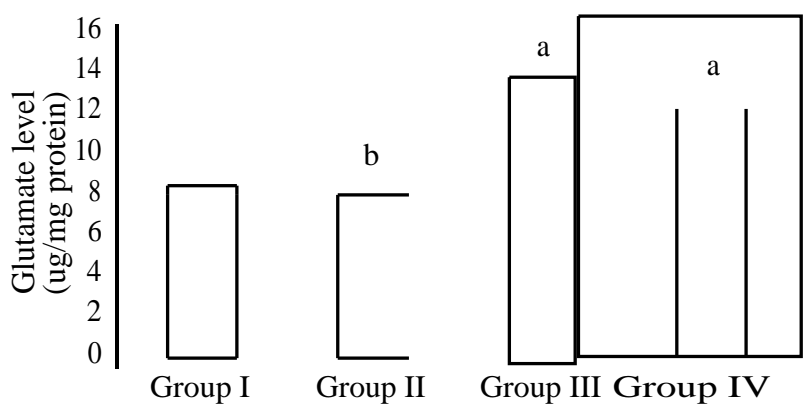

Fig. (1): Effect of Se treatment on glutamate levels in rats hippocampi.

Group I : Normal control. $\quad$ Data are expressed as mean \pm SD Group II : Drug control. a: $p<0.05$ Vs. Group I. Group III : CRS. $\quad$ b: $p<0.05$ Vs. Group III. Group IV : Se-treated CRS groups.

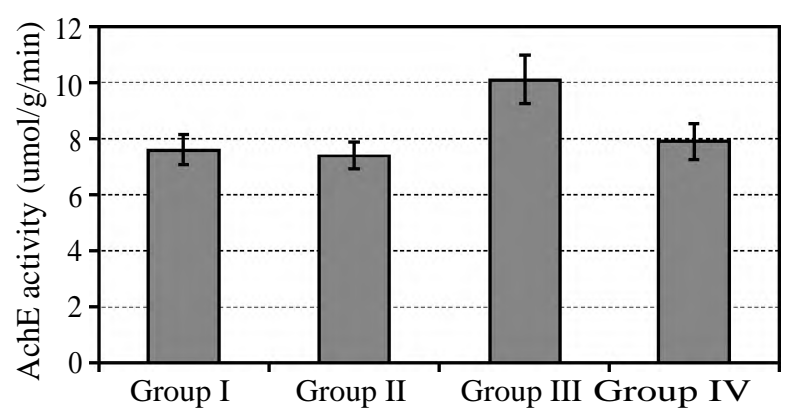

Fig. (2): Effect of Se treatment on AchE activity levels in rats hippocampi.

Group I : Normal control. $\quad$ Data are expressed as mean \pm SD Group II : Drug control. Group III : CRS. Group IV : Se-treated CRS groups. a: $p<0.05$ Vs. Group I. b: $p<0.05$ Vs. Group III 


\section{Discussion}

This current study was designated to explore the possible protective potential of Se on CRS induced memory deficits in rats. The main finding of this work was that, 21 days of Se treatment reversed the CRS induced memory deficits which correlated with attenuation of biochemical parameters in the hippocampus.

Our investigations supported the hypothesis of that CRS impairs memory performance as indicated by a significant decrease in the time of latency to enter the dark compartment in PA task together with the decreased spontaneous alteration performance in T maze and decreased RI index in object recognition tasks upon CRS exposure, these results were in conformity with previous studies $[39,40]$ In contrast to the present findings, one study recorded the habituation of animals to chronic stress [41]. This discrepancy may be attributed to difference in the types and durations of stress evoked or the task paradigm used in both studies [42]

The mechanism of CRS induced memory deficits is multifactorial. Noteworthy, results herein demonstrated a significantly increased TBARS with decreased TrxR and GPx antioxidants levels in hippocampi of CRS exposed rats compared to control ones, indicating a triggered oxidative stress response, which came in line with previous studies [9]. Oxidative stress induced lipid peroxidation results in alteration of synaptic membrane depolarization, dysfunction of neurotransmission systems [43], and may lead to atrophy and even death of hippocampal neurons [44]. In addition, the maintenance of normal levels of GSH and TrxR antioxidants was shown to be critical in acquisition of spatial memory, since their deficiency triggers hippocampal apoptosis and failure of synaptic plasticity mechanisms which related to spatial memory impairment $[\mathbf{4 5 , 4 6 ]}$. Taken together, these data suggested an emerging role of antioxidants in modulating such memory deficits.

Appealingly, our investigations showed that $\mathrm{Se}$ cotreatment dampened the CRS evoked oxidative stress response and thereby, alleviated the subsequent pathological events underlying the CRS induced memory impairment as supported previously $[20,22]$. Selenium antioxidant capacity may be attributed to its promotion to transcription and enzymatic activity of many antioxidant enzymes including TrxR and GPx [22], or due to its scavenging to reactive oxygen species from brain tissue preventing lipid peroxidation [24,47]. Moreover, seleno-derivatives, acting as antioxidants was shown to directly affect synaptic transmission and/or plasticity improving memory performance $[16,48,49]$

BDNF, a neurotrophic growth factor, widely expressed in the hippocampus [50] and has a pivotal role in regulation of neuronal transmission and plasticity with potentiation of memory consolidation [51]. In contrast, $A \beta$ protein is well documented for its neurotoxicity and its deleterious effect on synaptic function with its involvement in memory loss in various neurological disorders [52]

The results obtained herein showed a significantly decreased BDNF while increased A $\beta$ levels in hippocampi of CRS exposed rats compared to control ones, suggesting their integration in the pathology of CRS induced cognitive deficits, which was inconsistence with previous studies [52-55].

An interrelation between amyloid $\beta$ and BDNF was documented, since $A \beta$ may trigger its neurotoxicity partly via down regulation of proteins integrated in the transcription of BDNF [56,57] Moreover, the decreased level of BDNF under chronic stress conditions may interfere with the repair process and consequently exacerbating the effect of $A \beta$ protein [58]. Meanwhile, stress itself may induce $A \beta$ accumulation via its alteration to the processing and production of Amyloid Precursor Protein (APP) and driving its processing toward the amyloidogenic pathway with subsequent increased $A \beta$ levels $[\mathbf{5 2 , 5 9 ]}$

Interestingly, Se co-treatment significantly counteracted the notable changes in BDNF and A $\beta$ levels, giving an evidence of their involvement in its neuroprotective effect in this rat model, which agree previous studies $[\mathbf{6 0 , 6 1 ]}$. The attenuating effect of Se on BDNF and A $\beta$ levels may be attributed to its antioxidant capacity, as the relation between oxidative stress, the reduction in BDNF level and $A \beta$ overproduction was previously documented $[49,62]$. In addition, the suppressing effect of Se on $\mathrm{A} \beta$ pathology may be mediated by its inhibition to APP with subsequent increasing the turnover of $A \beta$, decreasing its accumulation $[63,64]$. Consequently, this inhibition to $A \beta$ molecules also may release the BDNF from its inhibition by A $\beta$ overproduction, restoring its normal level, as mentioned above.

Tau protein is a member of microtubuleassociated proteins family, stabilizing axonal microtubules, facilitating diverse processes as axonal transport and synaptogenesis, with tau phosphorylation being critical for normal function and is 
the main mediator of the pathological properties of tau $[65,66]$

The results obtained herein showed that behavioral impairment was associated with a significant elevated levels of p-TAU in CRS group compared to normal control one, which could be attributed to decreased protein phosphatases 2A (MAP2) or activation of glycogen synthase kinase $3 \beta$ (GSK3 $\beta$ ), the main regulators of TAU phosphorylation $[67,68]$

Accumulation of p-Tau was suggested to be essential for chronic stress to induce dendritic atrophy and interrupt neuronal connectivity in the hippocampus [66,69]. Moreover, a sequestration of p-TAU into an insoluble pre pathogenic form may also occur under stress condition, which may constitute a link between stress and an AD-related pathogenic mechanism [70]

On the other hand, Se co-treatment significantly attenuated the increased levels of p-TAU in hippocampi of treated CRS group compared to untreated one. In consistence, selenium improved TAU pathology in AD rat models [16,71], further the improvement in learning and memory in selenium-treated tau transgenic mice was suggested to be mediated by its diminution to hippocampal p-tau levels [72].

The suppressing effect of Se on p-TAU overproduction could be attributed to its modulating effect on Akt/GSK3 $\beta$ and/or PP2A activities [7274] or may be mediated by indirectly reducing the oxidative stress induced tau toxic species with subsequent improving memory performance $[\mathbf{1 6 , 4 9}]$ In addition, suppression to $A \beta$ pathology under Se treatment may have a role, since A $\beta$ was shown to trigger tau phosphorylation, most probably via $A \beta$ induced protease activation [75], and upregulation of GSK-3 $\beta$ [76]

Among the large number of stress induced neurochemical changes, excessive release of glutamate, the predominant excitatory neurotransmitter in brain, was suggested to play an important role in chronic stress induced hippocampal neurotoxicity [77]. In consistance, the results of the present work demonstrated a significant elevated level of hippocampal glutamate in CRS group compared to normal control one, which could be attributed to decreased hippocampal glutamate clearance and increased glutamate release from synaptosomes under chronic stress conditions [78]. Moreover, it was recorded that restraint stress induced spatial memory impairment was blocked by inhibiting glutamate release or interrupting its excitatory inputs to the hippocampus, suggesting a role of glutamate neurotoxicity in stress induced memory deficits [79].

The results obtained herein also demonstrated an insignificant effect of Se treatment on hippocampal level of glutamate of treated CRS group, nevertheless, studies recorded that Se may indirectly counteracted glutamate induced neurotoxic insult in hippocampal neurons by different mechanism [80], and that Se deficiency may increase the susceptibility to neurotoxic insults of glutamate [81], these data may give the assumption that the effect of se on glutamate toxicity may be mediated indirectly through antagonizing its toxic effects rather than affecting its basal level.

Acetylcholine-esterase is a key enzyme for correct cholinergic transmission, with its excessive activity had been associated with cognitive and memory impairment in different experimental models $[\mathbf{8 2 , 8 3}]$.

In this current study and in accordance with previous studies [77,84], CRS exposure led to excessive activation of hippocampal AChE enzyme. Meanwhile this activity was inhibited under Se co-treatment which may be another explaining mechanism of its alleviating effect on memory. Consistently anticholinesterases were shown to be effective in modulating memory deficits [85]. Moreover, Pinton et al., [86] reported that organoselenium reversed the increased activity of Ach E improving learning and cognitive deficits induced by intracerebro-ventricular injection of streptozotocin, which may be mediated at least in part by its antioxidant activity, especially that oxidative stress induced activation to AchE had been assumed previously [87]

\section{Conclusion:}

As proved in this current work, Se could alleviate the CRS-evoked memory deficits in rats. Its neuroprotective mechanism might be explained by its antioxidant potential, its augmentation to BDNF, its modulating effect on abnormal $A \beta$ and TAU pathologies, as well as its attenuation to AchE activity in the hippocampi of CRS exposed rats. These data suggested the potential therapeutic value of Se for memory dysfunction associated with stress and its related disorders, thus further studies are needed to replicate this work on human beings.

\section{Acknowledgment:}

We would like to thank dr. Doaa Radwan, the lecturer of anatomy at Tanta Faculty of Medicine for her kind assistance in dissection of rats hippocampi. 


\section{Conflict of interest:}

We have no conflict of interest to declare.

\section{References}

1- DASTGERDI A.H., RADAHMADI M. POURSHANAZARI A.A. and DASTGERDI H.H.: Effects of crocin on learning and memory in rats under chronic restraint stress with special focus on the hippocampal and frontal cortex corticosterone levels. Adv. Biomed. Res., 26 (6): 157, 2017.

2- WANG Q.M., WANG G.L. and MA Z.G.: Protective effects of myricetin on chronic stress-induced cognitive deficits. Neuro. Report, 27 (9): 652-8, 2016.

3- ZHANG Q., WANG X., BAI X., XIE Y., ZHANG T., BO S. and CHEN X.: Resveratrol reversed chronic restraint stress-induced impaired cognitive function in rats. Mol. Med. Rep., 16 (2): 2095-100, 2017.

4- MCEWEN B.S. and MAGARINOS A.M.: Stress and hippocampal plasticity: Implications for the pathophysiology of affective disorders. Hum. Psychopharmacol., 16: 7-19, 2001

5- KIM J.J. and DIAMOND D.M.: The stressed hippocampus, synaptic plasticity and lost memories. Nat . Rev. Neurosci., 3: 453-62, 2002.

6- MACHADO A., HERRERA A.J., De PABLOS R.M., ESPINOSA-OLIVA A.M., SARMIENTO M., AYALA A., et al.: Chronic stress as a risk factor for Alzheimer's disease. Rev. Neurosci., 25: 785-804, 2014.

7- GHADRDOOST B., VAFAEI A.A., RASHIDY-POUR A., HAJISOLTANI R., BANDEGI A.R., MOTAMEDI F., et al.: Protective effects of saffron extract and its active constituent crocin against oxidative stress and spatial learning and memory deficits induced by chronic stress in rats. Eur. J. Pharmacol., 667: 222-9, 2011.

8- ZHANG Y., LIU W., ZHOUD Y., MA C., LI S. and CONG B.: Endoplasmic reticulum stress is involved in restraint stress-induced hippocampal apoptosis and cognitive impairments in rats. Physiology \& Behavior, 131: 41-8, 2014.

9- ZAFIR A. and BANU N.: Induction of oxidative stress by restraint stress and corticosterone treatments in rats. Indian J. Biochem. Biophys., 46 (1): 53-8, 2009.

10- HUANG R.R., HU W., YIN Y.Y., WANG Y.C., LI W.P. and LI W.Z.: Chronic restraint stress promotes learning and memory impairment due to enhanced neuronal endoplasmic reticulum stress in the frontal cortex and hippocampus in male mice. Int. J. Mol. Med., 35: 553-9, 2015.

11- ORTIZ J.B., MATHEWSON C.M., HOFFMAN A.N., HANAVAN P.D., TERWILLIGER E.F. and CONRAD C.D.: Hippocampal brain-derived neurotrophic factor mediates recovery from chronic stress-induced spatial reference memory deficits. Eur. J. Neurosci., 40: 335162, 2014.

12- WOO H.W., HONG C.J., JUNG S., CHOE S. and YU S.W.: Chronic restraint stress induces hippocampal memory deficits by impairing insulin signaling. Mol. Brain, 11: 37, 2018.
13- PETERS M.M., HILL K.E., BURK R.F. and WEEBER E.J.: Altered hippocampus synaptic function in selenoprotein P deficient mice. Mol. Neurodegener., 1: 12, 2006.

14- TINGGI U.: Selenium: Its role as antioxidant in human health. Environ. Health Prev. Med., 13 (2): 102-8, 2008.

15- SANTAMARÍA A., SALVATIERRA-SÁNCHEZ R., VÁZQUEZ-ROMÁN B., SANTIAGO-LÓPEZ D., VILLEDA-HERNÁNDEZ J., GALVÁN-ARZATE S., et al.: Protective effects of the antioxidant selenium on quinolinic acid-induced neurotoxicity in rats: In vitro and in vivo studies. J. Neurochem., 86 (2): 479-88, 2003.

16- VAN DER JEUGD A., PARRA-DAMAS A., BAETACORRAL R., SOTO-FAGUÁS C.M., AHMED T., LAFERLA F.M., et al.: Reversal of memory and neuropsychiatric symptoms and reduced tau pathology by selenium in 3xTg-AD mice. Sci. Rep., 8: 6431, 2018.

17- SCHWEIZER U., BRÄUER A.U., KÖHRLE J., NITSCH R. and SAVASKAN N.E.: Selenium and brain function: A poorly recognized liaison. Brain Res. Brain Res. Rev., 45: 164-78, 2004.

18- RITA CARDOSO B., SILVA BANDEIRA V., JACOBFILHO W. and FRANCISCATO COZZOLINO S.M.: Selenium status in elderly: Relation to cognitive decline. J. Trace Elem. Med. Biol., 28: 422-6, 2014.

19- CHEN J. and BERRY M.J.: Selenium and selenoproteins in the brain and brain diseases. J. Neurochem., 86: 1-12, 2003.

20- BALABAN H., NAZ1RO GLU M., DEMIRCI K. and SUAT Ö.I.: The protective role of selenium on scopolamine-induced memory impairment, oxidative stress, and apoptosis in aged rats: The Involvement of TRPM2 and TRPV1 channels. Mol. Neurobiol., 54 (4): 2852-68, 2017.

21- HAN X.J., XIAO Y.M., AI B.M., HU X.X., WEI Q. and HU Q.S.: Effects of organic selenium on lead-induced impairments of spatial learning and memory as well as synaptic structural plasticity in rats. J. STAGE, 37 (3): 466-74, 2014.

22- TOMAS-SANCHEZ C., BLANCO-ALVAREZ V.M., MARTINEZ-FONG D., GONZALEZ-BARRIOS J.A., GONZALEZ-VAZQUEZ A., AGUILAR-PERALTA A.K., et al.: Prophylactic Zinc and therapeutic selenium administration increases the antioxidant enzyme activity in the rat temporoparietal cortex and improves memory after a transient hypoxia-ischemia. Oxidative Medicine and Cellular Longevity . Oxid. Med. Cell Longev., 2018: 9416432, 2018.

23- NEHRU B., DUA R. and IYER A.: Effect of Selenium on Lead-lnduced Alterations in Rat Brain. Journal of Environmental Biology, 30 (5): 859-64, 2009.

24- ATIF F., YOUSUF S. and AGRAWAL S.K.: Restraint stress-induced oxidative damage and its amelioration with selenium. European Journal of Pharmacology, 600: 5963, 2008.

25- KIM J.S., LEE H.J., KIM J.C., KANG S.S., BAE C.S., SHIN T., et al.: Transient impairment of hippocampusdependent learning and memory in relatively low-dose of acute radiation syndrome is associated with inhibition of hippocampal neurogenesis. Journal of Radiation Research, 49: 517-26, 2008. 
26- ZHANG M., MOON C., CHAN G.C., YANG L., ZHENG F., CONTI A.C., et al.: Ca stimulated type 8 adenylyl cyclase is required for rapid acquisition of novel spatial information and for working/episodic-like memory. Journal of Neuroscience, 28: 4736-44, 2008.

27- MONLEON S., URQUIZA A., VINADER-CAEROLS C. and PARRA A.: Effects of oxotremorine and physostigmine on the inhibitory avoidance impairment produced by amitriptyline in male and female mice. Behav. Brain Res., 205 (2): 367-71, 2009.

28- VORHEES C.V. and WILLIAMS M.T.: Assessing Spatial learning and memory in rodents. ILAR.J., 55 (2): 310 32, 2014.

29- HUGHES R.N.: The value of spontaneous alternation behavior (SAB) as a test of retention in pharmacological investigation of memory. Neurosci. Bio. Behav. Rev., 28 (5): 497-505, 2004.

30- DEACON R.M. and RAWLINS J.N.: T-maze alternation in the rodent. Nat. Protoc., 1 (1): 7-12, 2006.

31- BROADBENT N.J., GASKIN S., SQUIRE L.R. and CLARK J.: Object recognition memory and the rodent hippocampus. Learn. Mem., 17 (1): 5-11, 2010.

32- BEVINS R.A. and BESHEER J.: Object recognition in rats and mice: A one-trial non-matching-to-sample learning task to study 'recognition memory'. Nat. Protoc., 1 (3): 1306-11, 2006.

33- BRADFORD M.M.: A rapid and sensitive method for the quantitation of microgram quantities of protein utilizing the principle of protein-dye binding. Anal. Biochem., 72: 248-54, 1976

34- OHKAWA H., OHISHI N. and YAGI K.: Assay for lipid peroxides in animal tissues by thiobarbituric acid reaction. Anal. Biochem., 95 (2): 351-8, 1979.

35- CHIU D.T., STULTS F.H. and TAPPEL A.L.: Purification and properties of rat lung soluble glutathione peroxidase. Biochim. Biophys. Act., 445: 558-8, 1976.

36- HOLMGREN A. and BJORNSTEDT M.: Thioredoxin and thioredoxin reductase. Methods Enzymol., 252: 199208, 1995.

37- ELLMAN G.L., COURTNEY K.D. and ANDREAS J.V.: Feather-Stone RM. A new and rapid colorimetric determination of acetylcholinesterase activity. Biochem. Pharm., 7: 88-90, 1961.

38- GORUN V., PROINOV I., BALTESCU V., BALABAN G. and BARZU O.: Modified Ellman procedure for assay of cholinesterases in crude enzymatic preparation. Anal. Biochem., 86: 324-6, 1978.

39- KUMAR R.S., NARAYANAN S.N. and NAYAK S.: Ascorbic acid protects against restraint stress-induced memory deficits in wistar rats. Clinics (Sao Paulo), 64 (12): 1211-7, 2009

40- LI X.A., CHEN L., LUO B., LI X., WANG C.Y., ZOU W., et al.: Hydrogen sulfide attenuates chronic restrain stress-induced cognitive impairment by upreglulation of Sirt1 in hippocampus. Oncotarget., 8 (59): 100396-410, 2017.

41- MCEWEN B.S. and MAGARINOS A.M.: Stress and hippocampal plasticity: Implications for the pathophysi- ology of affective disorders. Hum Psychopharmacol., 16: S7-S19, 2001

42- RANJBAR H., RADAHMADI M., ALAEI H., REISI P. and KARIMI S.: The effect of basolateral amygdala nucleus lesion on memory under acute, mid and chronic stress in male rats. Turk. J. Med. Sci., 46: 1915-25, 2016.

43- FUKUI K., OMOI N., HAYASAKA T., SHINNKAI T., SUZUKI S., ABE K. and URANO S.: Cognitive impairment of rats caused by oxidative stress and aging, and its prevention by Vitamin E. Annals of the New York Academy of Sciences, 959: 275-84, 2002.

44- SALEHI A., RABIEI Z. and SETORKI M.: Effect of gallic acid on chronic restraint stress-induced anxiety and memory loss in male BALB/c mice. Iran J. Basic Med. Sci., 21: 1232-7, 2018.

45- CRUZ R., ALMAGUER MELIAN W. and BERGADO ROSADO J.A.: Glutathione in cognitive function and neurodegeneration. Rev. Neurol., 36: 877-86, 2005.

46- YANG X.H., LIU H.G., LIU X. and CHEN J.N.: Thioredoxin and impaired spatial learning and memory in the rats exposed to intermittent hypoxia. Chinese Medical Journal, 125: 3074-80, 2012.

47- ABOU ZAID O.A.R., EL-SONBATY S.M. and BARAKAT W.E.M.: Ameliorative effect of selenium nanoparticles and ferulic acid on acrylamide-induced neurotoxicity in rats. Annals of Medical and Biomedical Sciences, 3 (2): 35-45, 2017.

48- BECKHAUSER T.F., FRANCIS-OLIVEIRA J. and DEPASQUALE R.: Reactive oxygen species: Physiological and physiopathological effects onsynaptic plasticity. J. Exp. Neurosci., 10: 23-48, 2016.

49- TONNIES E. and TRCHINA E.: Oxidative stress, synaptic dysfunction, and Alzheimer's disease. J. Alzheimers. Dis. 57: 1105-21, 2017.

50- JIAO S.S., SHEN L.L., ZHU C., BU X.L., LIU Y.H., LIU C.H., et al.: Brain-derived neurotrophic factor protects against tau-related neuro degeneration of Alzheimer's disease. Transl. Psychiatry, 6 (10): e907, 2016.

51- BATHINA S. and DAS U.N.: Brain-derived neurotrophic factor and its clinical implications. Arch. Med. Sci., 11 (6): 1164-78, 2015.

52- DONG H. and CSERNANSKY J.G.: Effects of Stress and Stress Hormones on Amyloid-P Protein and Plaque Deposition. J. Alzheimers Dis., 18 (2): 459-69, 2009.

53- LUCASSEN P.J., MEERLO P., NAYLOR A.S., VAN DAM A.M., DAYER A.G., FUCKS E., et al.: Regulation of adult neurogenesis by stress, sleep disruption, exercise and inflammation: Implications for depression and antidepressant action. Eur. Neuropsycho. Pharmacol., 20: 117, 2010.

54- RADAHMADI M., ALAEI H., SHARIFI M.R and HOSSEINI N.: Effects of different timing of stress on corticosterone, BDNF and memory in male rats. Physiol. Behav., 139: 459-67, 2015.

55- ROSA E. and FAHNESTOCK M.: CREB expression mediates amyloid b-induced basal BDNF downregulation. Neurobiol. Aging, 36 (8): 2406-13, 2015.

56- WALTON M.R. and DRAGUNOW I.: Is CREB a key to neuronal survival? Trends. Neurosci., 23: 48e53, 2000. 
57- PRUUNSILD P., SEPP M., ORAV E., KOPPEL I. and TIMMUSK T.: Identification of ciselements and transcription factors regulating neuronal activity-dependent transcription of human BDNF gene. J. Neurosci., 31: 3295e3308, 2011.

58- ALEISA A.M., ALZOUBI K.H., GERGES N.Z. and ALKADHI K.A.: Chronic psychosocial stress-induced impairment of hippocampal LTP: Possible role of BDNF. Neurobiol. Dis., 22: 453-62, 2006.

59- SRIVAREERAT M., TRAN T.T., SALIM S., ALEISA A.M. and ALKADHI K.A.: Chronic nicotine restores normal $A \beta$ levels and prevents short-term memory and E-LTP impairment in A $\beta$ rat model of Alzheimer's disease. Neurobiol. Aging, 32: 834-44, 2011.

60- ABEDELHAFFEZ A.S. and HASSAN A.: Brain derived neurotrophic factor and oxidative stress index in pups with developmental hypothyroidism: Neuroprotective effects of selenium. Acta Physiol. Hung., 100 (2): 197 210, 2013.

61- GODOI G.L., De OLIVEIRA PORCIÚNCULA L., SCHULZ J.F., KAUFMANN F.N., DA ROCHA J.B., De SOUZA D.O., et al.: Selenium compounds prevent amyloid $\beta$-peptide neurotoxicity in rat primary hippocampal neurons . Neurochem. Res., 38 (11): 2359-63, 2013.

62- HACIOGLU G., SENTURK A., INCE I. and ALVER A.: Assessment of oxidative stress parameter of brain-derived neurotrophic factor heterozygous mice in acute stress model. Iran J. Basic. Med. Sci., 19 (4): 388-93, 2016.

63- SONG G.L., CHEN C., WU Q.Y., ZHANG Z.H., ZHENG R., CHEN Y., et al.: Selenium-enriched yeast inhibited $\beta$-amyloid production and modulated autophagy in a triple transgenic mouse model of Alzheimer's disease. Metallomics, 15, 10 (8): 1107-15, 2018.

64- NIGAM S.M., XU S., KRITIKOU J.S., MAROSI K., BRODIN L. and MATTSON M.P.: Exercise and BDNF reduce $A \beta$ production by enhancing $\alpha$-secretase processing of APP. J. Neurochem., 142 (2): 286-96, 2017.

65- SIERRA-FONSECA J.A. and GOSSELINK K.L.: Tauopathy and neurodegeneration: A role for stress. Neurobiology of Stress, 9: 105-12, 2018.

66- LOPES S., VAZ-SILVA J., PINTO V., DALLA C., KOKRAS N., BEDENK B., et al.: Tau protein is essential for stress-induced brain pathology. PNAS., 113 (26): 3755-63, 2016.

67- YAN J., SUN X.B., WANG H.Q., ZHAO H., ZHAO X.Y., XU Y.X., GUO J.C. and ZHU C.Q.: Chronic restraint stress alters the expression and distribution of phosphorylated tau and MAP2 in cortex and hippocampus of rat brain. Brain Res., 1347: 132-41, 2010.

68- RISSMAN R.A., LEE K.F., VALE W. and SAWCHENKO P.E.: Corticotropin-releasing factor receptors differentially regulate stress-induced tau phosphorylation. J. Neurosci., 27: 6552-62, 2007.

69- SOTIROPOULOS I., CATANIA C., PINTO L.G., SILVA R., POLLERBERG G.E., TAKASHIMA A., et al.: Stress acts cumulatively to precipitate Alzheimer's disease like tau pathology and cognitive deficits. J. Neurosci., 31: 7840-7, 2011

70- RISSMAN R.A., STAUP A., LEE A.R., JUSTICE N.J., RICE K.C., VALE W. and SAWCHENKO P.E.: Cortico- tropin-releasing factor receptor-dependent effects of repeated stress on tau phosphorylation, solubility, and aggregation. Proc. Natl. Acad. Sci. U.S.A., 109 (16): 6277-82, 2012.

71- SHULTZ S.R., WRIGHT D.K., ZHENG P., STUCHBERY R., LIU S.J., SASHINDRANATH M., et al.: Sodium selenate reduces hyperphosphorylated tau and improves outcomes after traumatic brain injury. Brain, 138: 1297 313,2015

72- VAN EERSEL J., KE Y.D., LIU X., DELERUE F., KRIL J.J., GÖTZ J. and ITTNER L.M.: Sodium selenate mitigates tau pathology, neurodegeneration, and functional deficits in Alzheimer's disease models. Proc. Natl. Acad. Sci. USA, 107: 13888-93, 2010.

73- SONG G., ZHANG Z., WEN L., CHEN C., SHI Q., ZHANG Y., NI J.I. and LIU Q.: Selenomethionine ameliorates cognitive decline, reduces tau hyperphosphorylation, and reverses synaptic deficit in the triple transgenic mouse model of Alzheimer's disease. J. Alzheimers Dis., 41: 85-99, 2014.

74- CORCORAN N.M., MARTIN D., HUTTER-PAIER B., WINDISCH M., NGUYEN T., NHEU L., et al.: Sodium selenate specifically activates PP2A phosphatase, dephosphorylates tau and reverses memory deficits in an Alzheimer's disease model. J. Clin. Neurosci., 17: 1025-33, 2010.

75- PARK S.Y. and FERREIRA A.: The generation of a 17 $\mathrm{kDa}$ neurotoxic fragment: An alternative mechanism by which tau mediates beta amyloid-induced neurodegeneration. J. Neurosci., 25 (22): 5365-75, 2005.

76- REIFERT J., HARTUNG-CRANSTON D. and FEINSTEIN S.C.: Amyloid beta mediated cell death of cultured hippocampal neurons reveals extensive tau fragmentation without increased full-length tau phosphorylation. J. Biol. Chem., 286 (23): 20797-811, 2011.

77- SUNANDA B.S., RAO S. and RAJU T.R.: Restraint stressinduced alterations in the Levels of biogenic amines, amino acids, and AChE Activity in the hippocampus. Neurochem. Res., 25: 1547-52, 2000.

78- De VASCONCELLOS-BITTENCOURT A.P., VENDITE D.A., NASSIF M., CREMA L.M., FROZZA R., THOMA ZI A.P., et al.: Chronic stress and lithium treatments alter hippocampal glutamate uptake and release in the rat and potentiate necrotic cellular death after oxygen and glucose deprivation. Neurochem. Res., 36: 793-800, 2011.

79- SUNANDA B.S., RAO S. and RAJU T.R.: Chronic restraint stress impairs acquisition and retention of spatial memory task in rats. Current Science, 79 (11): 1581-4, 2000.

80- MA Y.M., IBEANU G., WANG L.Y., ZHANG J.Z., CHANG Y., DONG J.D., et al.: Selenium suppresses glutamate-induced cell death and prevents mitochondrial morphological dynamic alterations in hippocampal HT22 neuronal cells. B.M.C. Neurosci., 18: 15, 2017.

81- SAVASKAN N.E., BRÄUER A.U., KÜHBACHER M., EYÜPOGLU I.Y., KYRIAKOPOULOS A., NINNEMANN O., et al.: Selenium deficiency increases susceptibility to glutamate-induced excitotoxicity. FASEB J., 17 (1): 112-4, 2003.

82- DESHMUKH R., KAUNDAL M. and BANSAL V.: Caffeic acid attenuates oxidative stress, learning andmemory 
deficit in intra-cerebroventricular streptozotocin induced experimental dementia in rats. Biomed. Pharmacother., 81: 56-62, 2015.

83- NGOUPAYE G.T., YASSI F.B., BAHANE D.A.N. and BUM E.N.: Combined corticosterone treatment and chronic restraint stress lead to depression associated with early cognitive deficits in mice. Metabolic Brain Disease, 33 (3): 1-11, 2017

84- ANURADHA H., SRIKUMAR B.N., DEEPTI N., SHANKARANARAYANA B.S. and LAKSHMANA M.: Restoration of acetylcholinesterase activity by Euphorbia hirta in discrete brain regions of chronically stressed rats. Pharm. Biol., 48 (5): 499-503, 2010.
85- SAXENA G., SINGH S.P., AGRAWAL R. and NATH C. Effect of donepezil and tacrine on oxidative stress in intracerebral streptozotocin-induced model of dementia in mice. Eur. J. Pharmacol., 581: 283-9, 2008.

86- PINTON S., Da ROCHA J.T., ZENI G. and NOGUEIRA C.W.: Organoselenium improves memory decline in mice: Involvement of acetylcholinesterase activity. Neuroscience Letters, 472: 56-60, 2010.

87- HÄRTL R., GLEINICH A. and ZIMMERMANN M. Dramatic increase in readthrough acetylcholinesterase in a cellular model of oxidative stress. Journal of Neurochemistry, 116 (6): 1088-96, 2011.

\section{التآثير الواقى المحتمل للسيلينيوم ضد إضطرابات الذاكرة

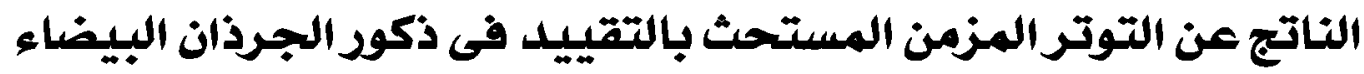

\footnotetext{
الهدف من الدراسة: تم تصميم هذه الدراسة الحالية لفحص تآثير العلاج بالسيلينيوم ضد إضطرابات الذاكرة الناجم عن التوتر المزمن المستحث بالتييي في فئران التجارب.

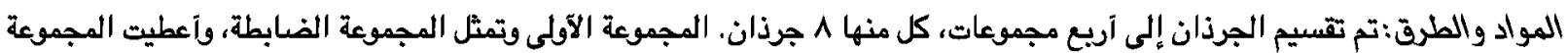

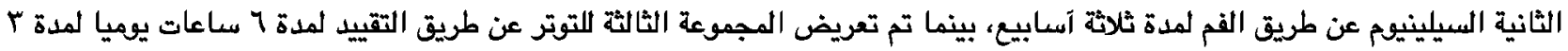

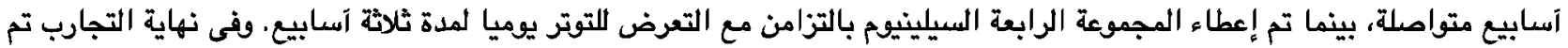

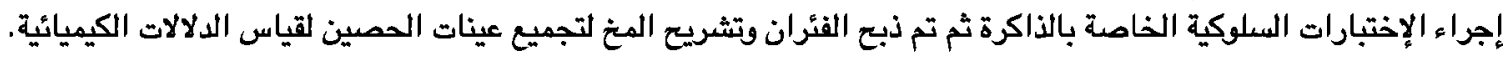

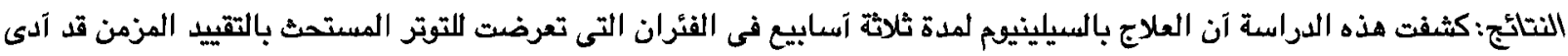

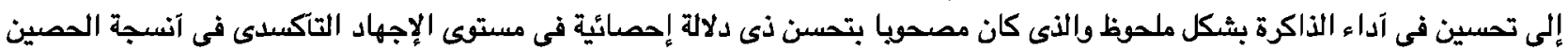

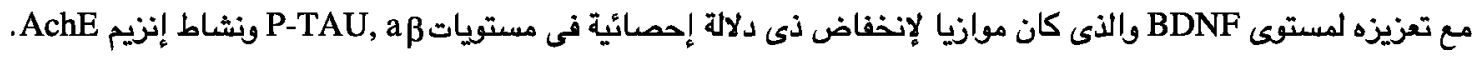
الخلاصة: هذه النتائج تثير إلى الآثار الواقية المفيدة اللسيلينيوم على إضطرابات الذاكرة الناتج عن التوتر المزمن المستحث بالتقييد
} 